日薬䧉祮 $57,66 \sim 77(1961)$

\title{
シギ夕リ ス作用機構
}

第 3 報 素質とジギタリス作用に関する実験的研焭

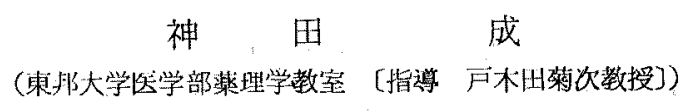

(炤和 35 年 6 月 30 日受付)

\section{まえがき}

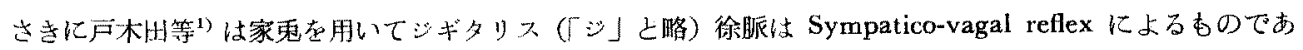

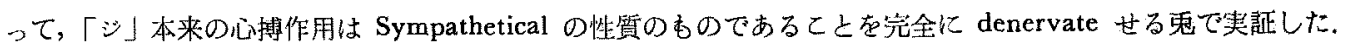
更に小田原》は第 2 報に於て䲸を用いてジ゙タリスの本来の心搏作用は鬼之同しくSympathetical のものである

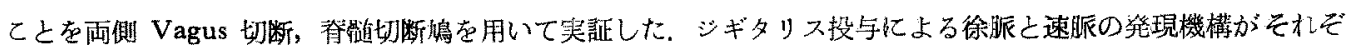

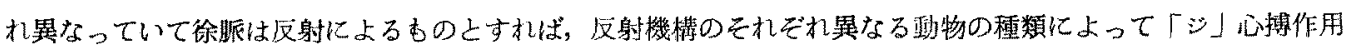

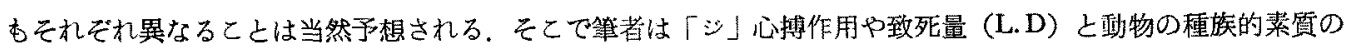

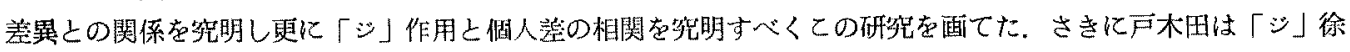
眽が絶対に発現しない処の Vagus 切断家象に50万倍 acethylcholin 溶液を持続注入 (2cc/minute) し乍ら「シ」

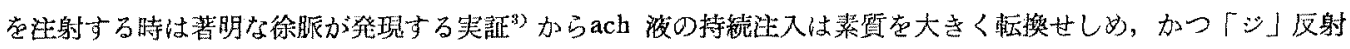

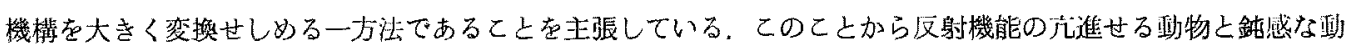
物とでは「シ」作用のあらわれかだがそれそれ異なることが推定される。

\section{実験方法と実験の進め方}

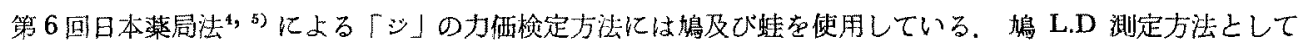

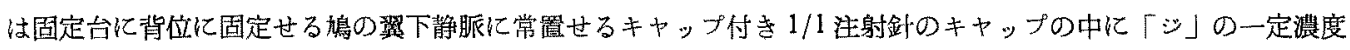

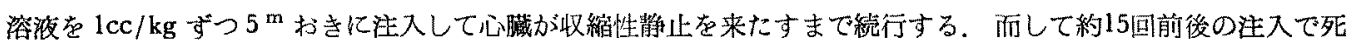

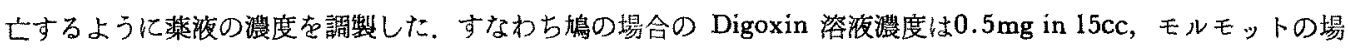
合は $0.5 \mathrm{mg}$ in $15 \mathrm{cc}$ ，ラットの場合は 1 回注入量 $0.0325 \mathrm{mg} / 100 \mathrm{~g}$ にした (Digosin 液 $0.13 \mathrm{cc} / 100 \mathrm{~g}$ ).

心電図測定は四肢誘導法により日本光電ペン書き心電計を用いた，胸部誘導は胸骨下端部に端子を設定した。 㲜物は背位に固定し頭部は体駆に一直線になるように位琵せしぬた。

はじめ種及の動物についての「シ」L.D と心搏曲線を測定し第 2 草にわいてはラットによる「ジ」作用につ いて副腎との関係およびグロクロンサン（g1、と狢）との関係等を梌索し続いて第 3 章においてモルモット(以下 モルと略)に対する「シ」作用をラットと同じ条件において梌討を扣壳た。

\section{第1 章 種族差による「ジ」作用の相迋}

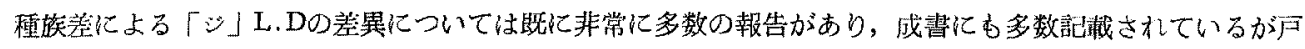

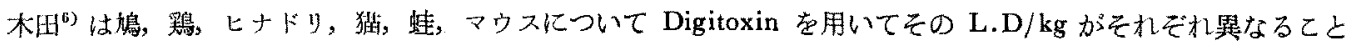
を報告している，その原因が何れにあるか⿰氵ついてはすべて報告者は何等の説明も加えていない．又「シ」L.D と動物種茬との相互関係は「シ」の種類によっても異なってくることは Digitoxin と Strophantin の L.D が猫 及び鬼でそれぞれ異るることによってあ解る，即ち Digitoxin の猫 L.D は鬼 L.D の約 1/8 であるに反し Strophantin の猫 L.D は象 L.D の約 $1 / 2$ でする゙．

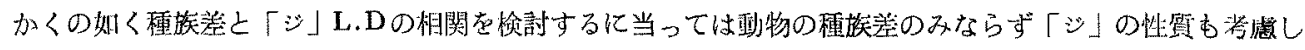
なり机ばならない。

従って筆者は使用せる「シ」としては，主として Digoxin を用いるととにした，とれは比較的速効性でし 
かも持続比が比較的に長時間である為に做体差が少ないからである。

1）猫, 鳩,「モル」及びラットの「ジ」L.D

$2 \sim 3 \mathrm{~kg}$ 前後体重の揵常猫，500g前後体冓の健常「モル」，150g前後体重の健常ラットの. Digoxin L.D を

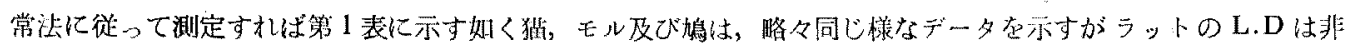
常に大量党必要とする。

第 1 表. 各程動物O Digoxin L. D.

\begin{tabular}{|c|c|c|c|c|c|c|c|}
\hline 験 動 物 名 & 例数 & L.D (平均) & 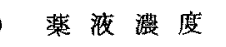 & 注 & 射 & 回 & 数 \\
\hline$(2.0 \mathrm{~kg} \sim 3.0 \mathrm{~kg})$ & 4 & $0.33 \mathrm{mg} / \mathrm{kg}$ & $0.5 \mathrm{mg}$ in $15 \mathrm{cc}$ & $9, \quad 9$ & 11 & 11 & \\
\hline 「モル」(500g $-600 \mathrm{~g})$ & 4 & $0.525 \mathrm{mg}$ & $0.5 \mathrm{mg}$ in $15 \mathrm{cc}$ & 13,15 & 15 & 18 & \\
\hline 沜 $(350 \mathrm{~g}-450 \mathrm{~g})$ & 6 & $0.45 \mathrm{mg}$ & $0.5 \mathrm{mg}$ in $15 \mathrm{cc}$ & $12, \quad 12$, & 13 & 13,15 & 16 , \\
\hline ラット $(150 \mathrm{~g}$ 前 後 $)$ & 6 & $4.44 \mathrm{mg}$ & $\begin{array}{l}(1 \text { 回量 } 0.13 \mathrm{cc}) \\
.0325 \mathrm{mg} / 100 \mathrm{~g}\end{array}$ & $12, \quad 12$ & 13 & 15,15 & 15 \\
\hline
\end{tabular}

2）各種動物の「ジ」心搏作用

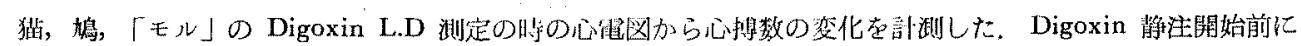

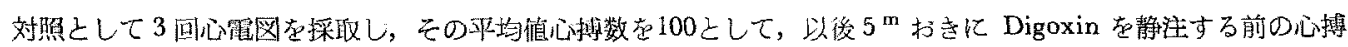

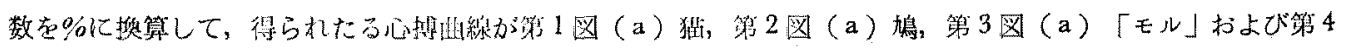
図 (a)ラットである.

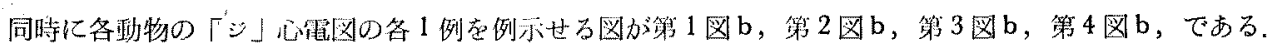

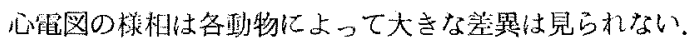

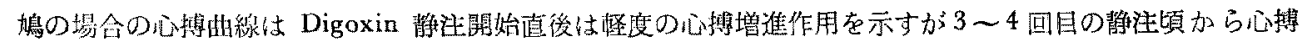
堿少をきたし7〜8回目頃は顕著な徐脈を示し続いて10回前後加ら死亡前まで心搏数增大を示す、猫，「モル及 びラットの場合は Digoxin 静注開始直後から，濑隇的な心搏数減少を示しているのが見られる。

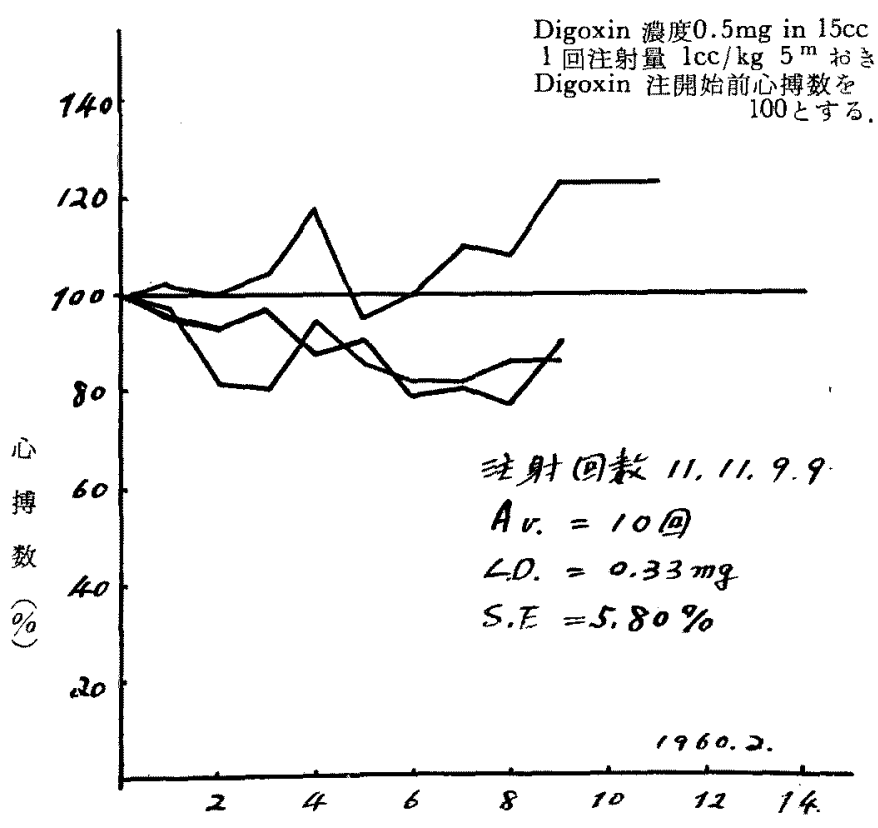

$5^{\mathrm{m}}$ 和き诖射回数
Cont. H.R. 200

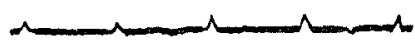

D-8 H.R. 154

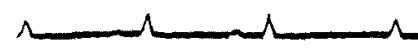

第 1 図b、六」 Digoxin E.K.G $3 \mathrm{~kg}$.

第 1 図a，猫のDigoxin LD 扩よび心搏曲線。 


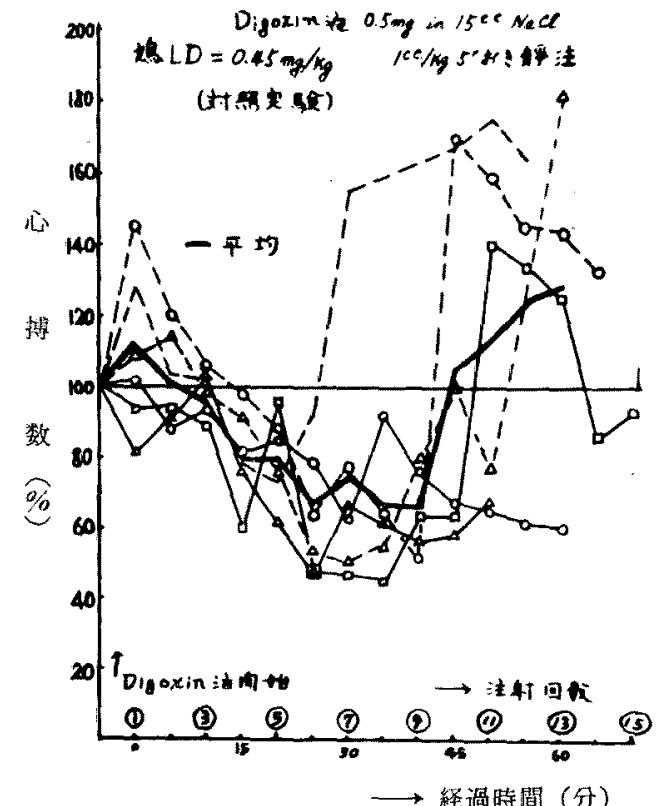

第 2 図a、ハトジギタリス心搏曲線。

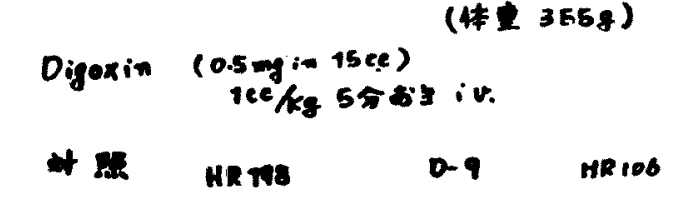

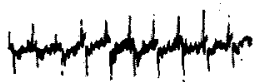

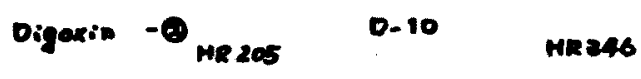

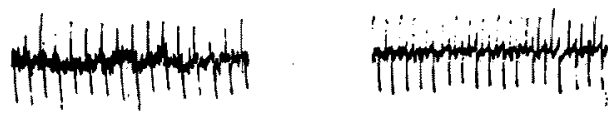

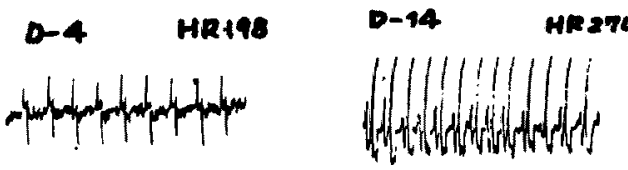

第2图b.八ト心電図。

Cont. H.R. 350

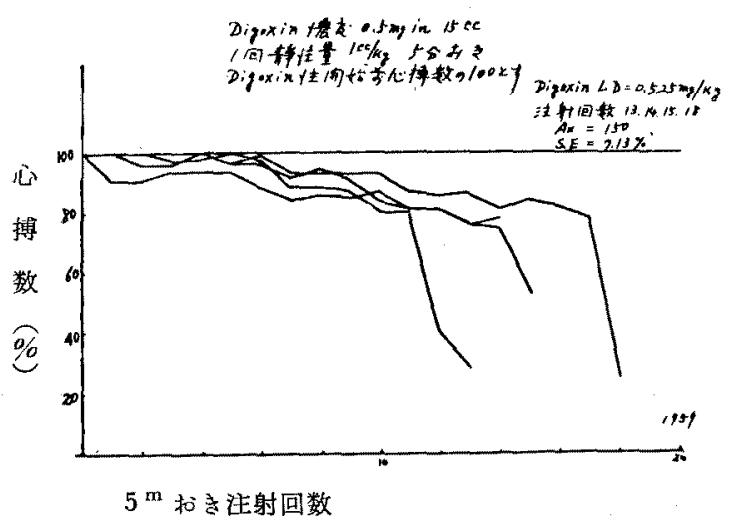

第3图a，健常モルモットの Digoxin L.D 扔よび心搏曲線。
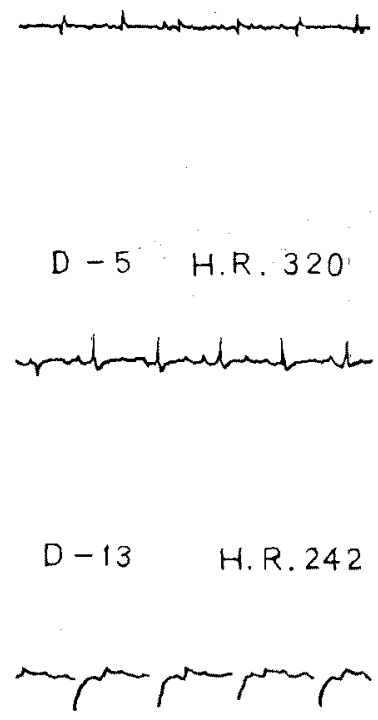

第 3 图b、モルモットDigoxin E.K.G $320 \mathrm{~g}$. 


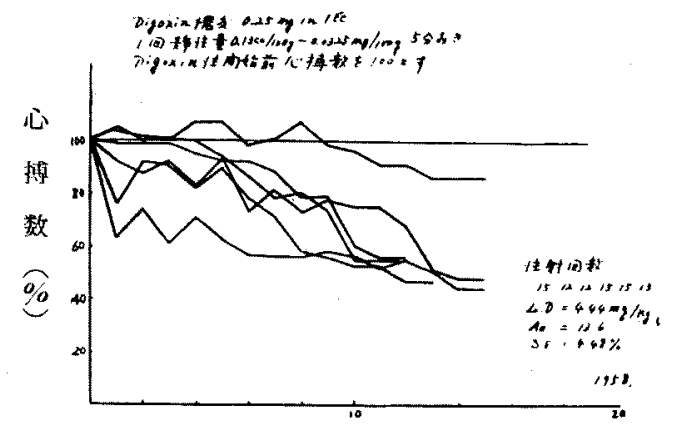

$5^{\mathrm{m}}$ 初き注射回数

第 4 図a. 揵常ラットの Digoxin L.D 扣よび心搏畃線。

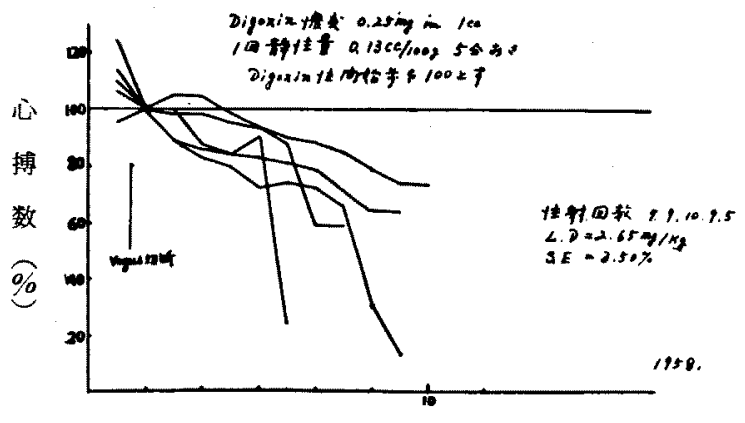

$5^{\mathrm{m}}$ 和き注射回数

第 5 図a. Vagus 切断ラッテのDigoxin L.D 打よび心搏曲線。

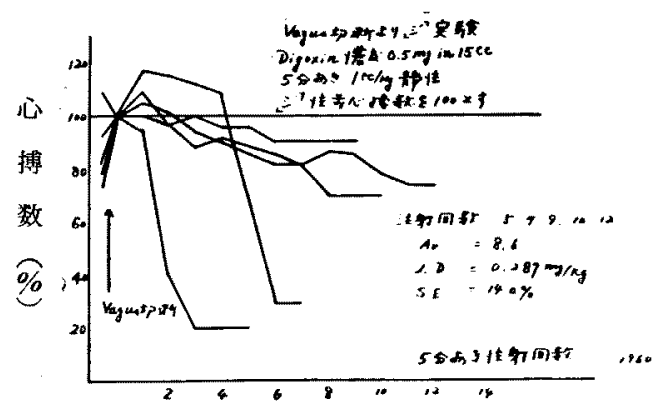

第6 図. Vagus 切断モルモットの Digoxin L.D 杖よび心 曲捕綜。
Cont. H.R. 315

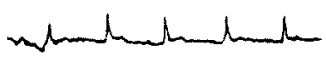

D $-3 \quad$ H.R. 294

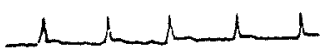

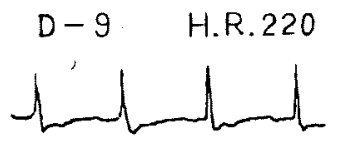

第 4 図b. 正常 $ッ$ 卜 Digoxin E.K.G $125 \mathrm{~g}$.

以上の牛物程菱による心搏数の变化の

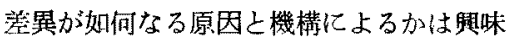
ある問題であって鳰の没射機構が非常に徽

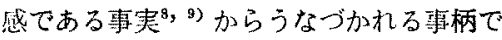
ある。

\section{3) Vagus との関係}

鵆の場合両㑡 Vagus 苍切断後に「シ」 作用を検するにL.Dは北化し，徐脈並び に速脈は完全に消失する ${ }^{2}$. ラットの場合 両側 Vagus を切断すると呼吸困難を来た して，それだけで数時間後には死亡するの で，人工呼吸を施しし作ら Digoxin L.Dを 求めるに第 5 园に示すような結果が得られ た。即ち「シ」徐脈は完全に消失しない。 「ル」の埸合も第6図に示すように、「シ」 徐脈は完全な消失は見られない。

L.D䲴の場合でむ「モル」やラット

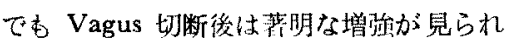

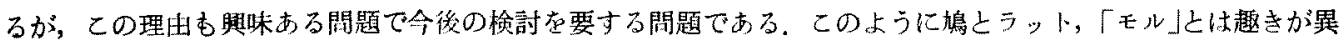
ると元わざる虑得ない。

\section{第 2 章 ラットに対する「シ」作用の検索}

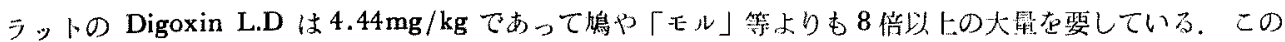
原因機作に関し副㹂機能わよび「gl」との関係を倹討して見た。

1）正常ラットの Digoxin L.D 及び心搏作用 
(前揭略)

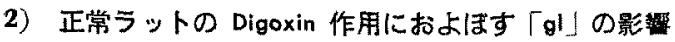

グルクロンサンソーダ (「gl. nat.」と略) $50 \mathrm{mg} / 100 \mathrm{~g}$ ずつを $5^{\mathrm{m}}$ おきに静注し乍ら「シ」L.D求めるに 第 7 図佂示す如くこの L.D は 6 例平均 $3.35 \mathrm{mg} / \mathrm{kg}$ となって力便が強化しているのが見られる.

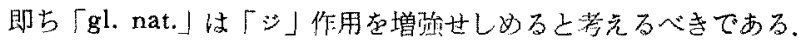

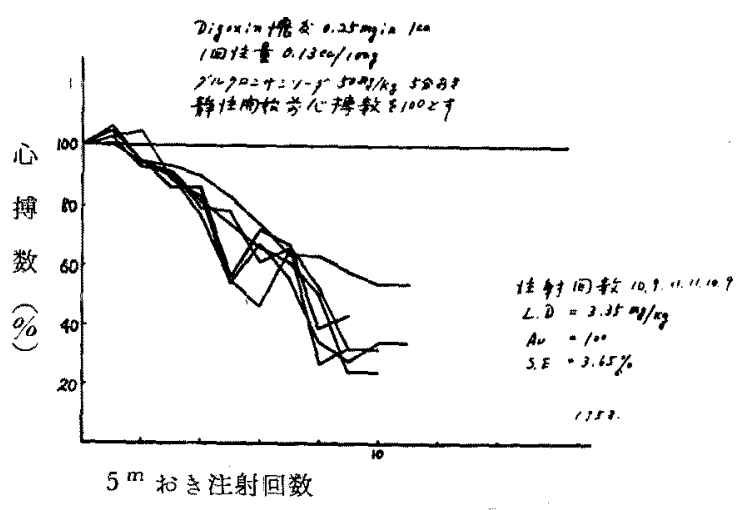

第 7 図.ダルクロンサン投与ラットの Digoxin L.D 括よび心搏的線。

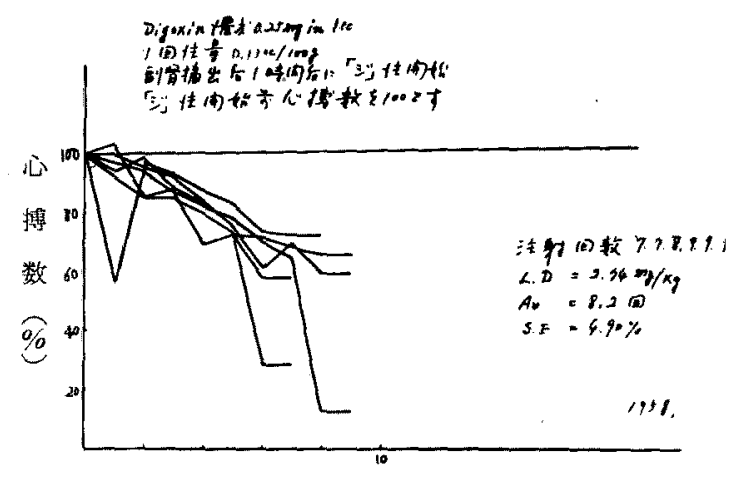

$5^{\mathrm{m}}$ 扝昰注射回数

第 8 図. 雨側副堅摘出ラットD Digoxin L.D と心 排曲線。

\section{3）禹側副腎摘出ラットの「ジ」作用}

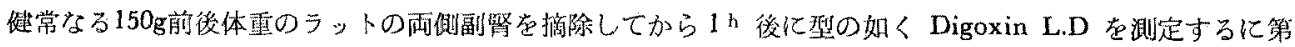

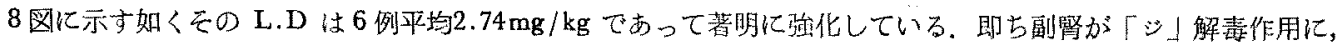
いか汸力に関与しているか力解る。

4) 浊側副摘ラットの「ジ」作用におよばす「gl,」の影製

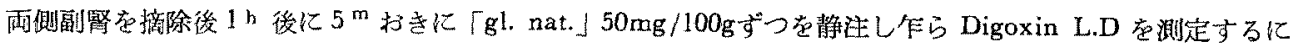
第 9 図に見る如くその L.D は 8 例平均 $3.10 \mathrm{mg} / \mathrm{kg}$ になて副腎機能不全時には「gl. nat.」が「シ」解毒機棈 に関与していることが明磪である。

さらに「gl. nat.」より屯作用の持続時間が化学的に長い ${ }^{10,11)}$ 之証䏣されている，グルクロンサンアミド(厂gl.

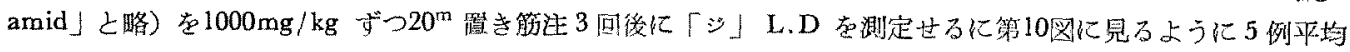

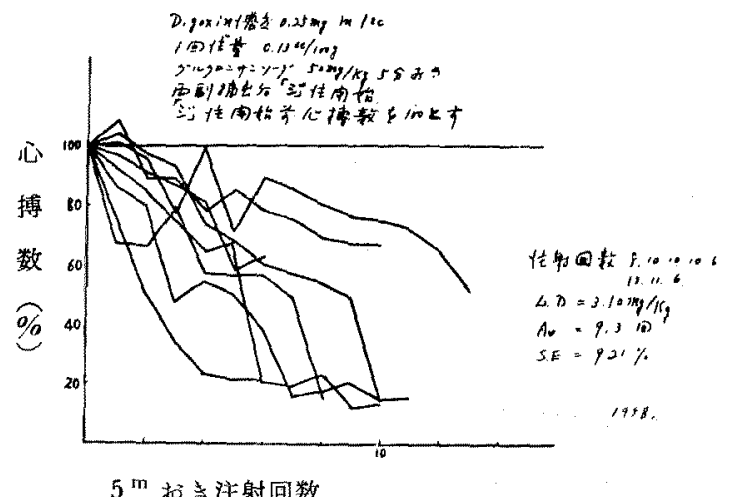

$5^{\mathrm{m}}$ 和吉注射回数

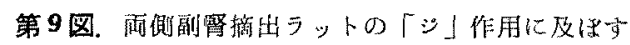
グルクロンサン投与の影繁.
L.D $3.54 \mathrm{mg} / \mathrm{kg}$ であって, 「gl, amid」の方が「gl.

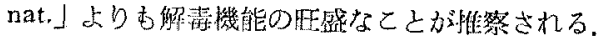

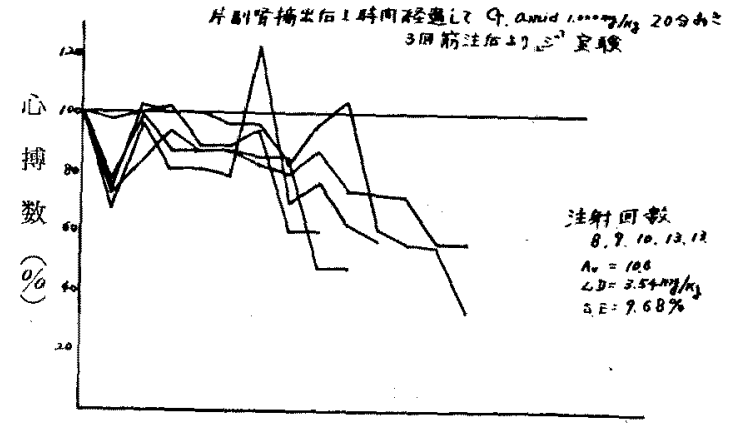

第10図. 片側副筲摘出ラットの Digoxin L.D 机改代心搏曲線。 


\section{5）ラット「ジ」作用に及ぼす副腎ホルモン投与の影整}

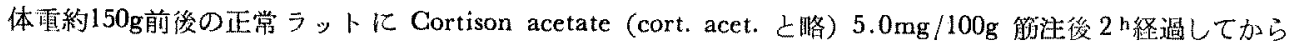

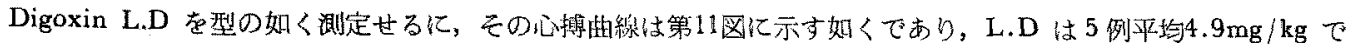
あった。

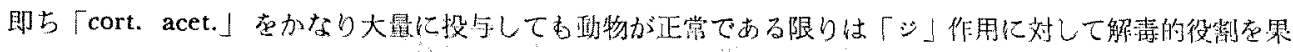

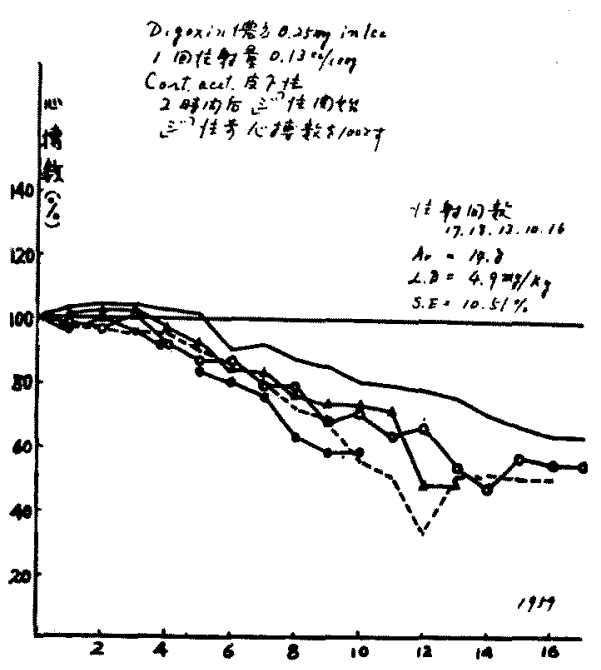

$5^{\mathrm{m}}$ 和吾注射回数

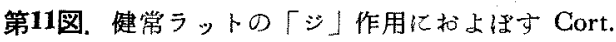
acet. $(5 \mathrm{mg} / 100 \mathrm{~g})$ 前処罳の影繁.

\section{たすことは教らられな．}

6) 副墑ラットに副腎ホルモン投与後における 「゙」作用

耐側副留を摘出してから $1 \mathrm{~h}$ 後に「cort. acet.」 $5 \mathrm{mg} / 100 \mathrm{~g}$ 投与して乘に 3 後に Digoxin L.D な 型の如く測定すると第12図に示す如き心搏曲線を現わ

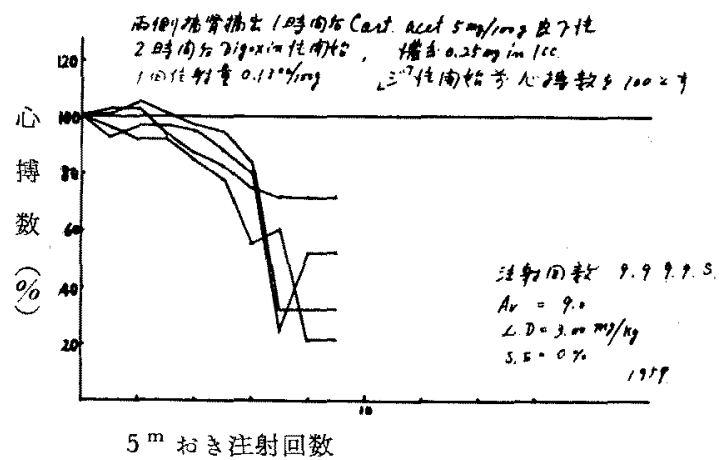

第12图，雨側副腎摘出ラットの「シ」作用に枕上ぼ す Cort. acet. 前処監 $の$ 影郘.

しその L.D は $3.0 \mathrm{mg} / \mathrm{kg}$ (4 例平均) であった。即ち副腎摘仙動物においては「 的役制果していると考えていい.

\section{7) ラットの「ジ」心搏作用}

健常ラットの Digoxin 心搏曲線は第4 図に示すように極めて徐々に60７0\%の心搏縟徐を来たすようにな るが Vagus 切断の場合は沜之異って徐脈の消失が菟られない（第5図）のはいかなる原因によるか明かでない．

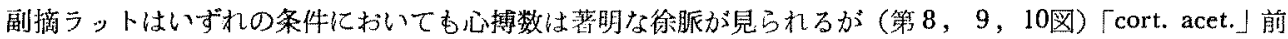
処置ラットでは正常の場合でも副腎摘除の場合であ徐脈は柽度であって死亡前に徐脈が現われるにすざない，

以上のことからラットの場合「シ」徐脈には副撉ホルモンが関与しているてとがうかがかれる。

8)小括

第 2 表、シットの程々条作時に和ける Digoxin L.D.

\begin{tabular}{|c|c|c|c|c|c|c|c|}
\hline ラットの条件（） & 外数 & Digoxin L.D. & & 洼 & 回 & 数 & 平均回数 \\
\hline 正常 ラ\% & (6) & 4.44 & 12 & $12,13,15$ & 15, & 15 & 13.6 \\
\hline Vagus 切断 & (5) & 2.65 & 5 & $7, \quad 9,9$ & 10 & & 8 \\
\hline gl. $50 \mathrm{mg}$ & (6) & 3.35 & 9 & $9,10,10$ & 11 & 11 & 10 \\
\hline 副捎 1 h 後 & (6) & 2.74 & 7 & $7, \quad 8, \quad 9$, & 9 & 9 & 8.1 \\
\hline 剖 掂 gl. amid. & (5) & 3.54 & 8 & $9,10,13$ & 13 & & 10.6 \\
\hline 融 挏 $\mathrm{gl}$. & (8) & 3.10 & 6 & $6, \quad 8,10$ & 10 & $10,11,13$ & 9.2 \\
\hline $\mathrm{it}$ 常 cort. acet. & (5) & 4.9 & 10 & $13,16,17$ & 18 & & 14.8 \\
\hline 墼摘 cort. acet, & (4) & 3.0 & 9 & $9, \quad 9, \quad 9$ & & & 9 \\
\hline
\end{tabular}


本章における実験デー夕を一括す机ば第 2 素に示す如くであって，「シ」の解毒に副腎がいが強力に関与し ているかが明らかである，ての副腎ホルモンによる解毒は健常正常時には著明でないが副腎機能不全時仙は副腎 ホルモンが「シ」解瑇に奏效するととがうかがわれる，更に「gl.」も正常時に於ては「シ」作用に対して大きな

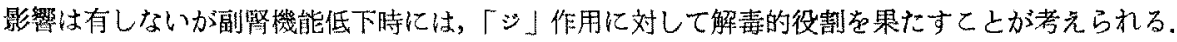

\section{第3章「モル」に対する「ジ」作用の梌索}

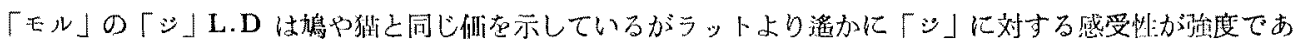
ろ.

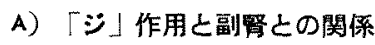

1）副腎ホルモン投与「モル」の「ジ」作用

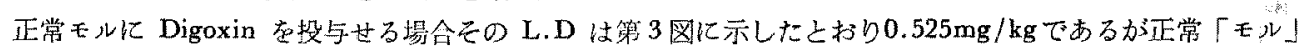

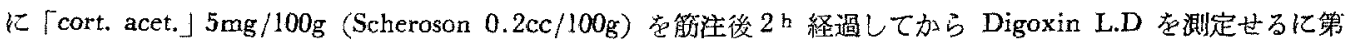

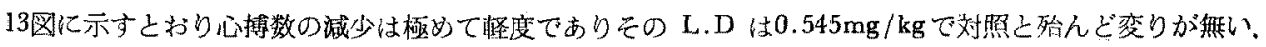

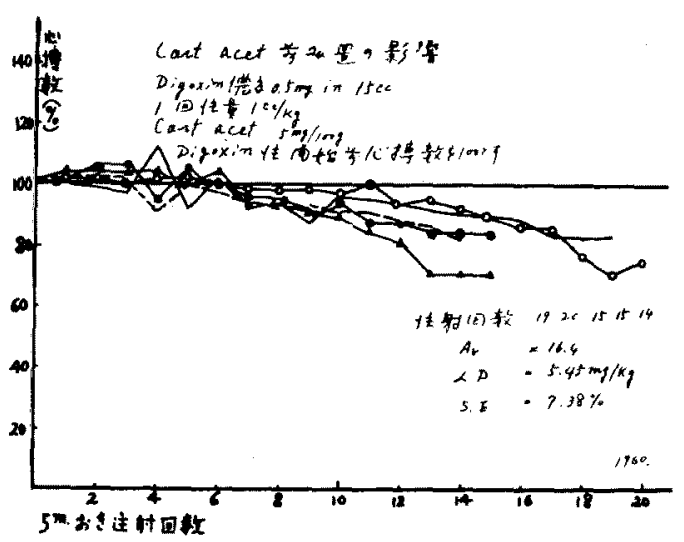

第13図、健常モルモットの Digoxin L.D 和よび心搏

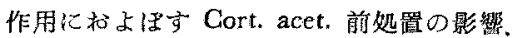

これに対し正常「モル」に「gl. nat. $1000 \mathrm{mg} / \mathrm{kg}$

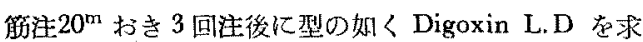
めたるに第13园bに見るように L.D は $0.454 \mathrm{mg} / \mathrm{kg}$ であって対照よりも柽度に增哥している。

2）片側副腎摘出「モル」の「シ」作用

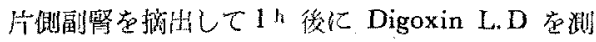
定せるに第14図化示与と扔り，4例平均 $0.44 \mathrm{mg} / \mathrm{kg}$ であって副腎摘出時は「モル」は「シ」に対する抵抗 力がかなり低下しているととがうかがかれる。

片側副摘に対し雨側副緊摘出後 1 h 経過してから Digoxin L.Dを求めたるに第14図bに見るように4 例 平㙏 L.Dは 有意の登は見ら扎なかった。

3) 片侧副㹂摘出 $+\lceil$ cort，acer. $](5 \mathrm{mg} / \mathbf{1 0 0 g})$ 投与 「モル」の流」作用（第15图）

片側副罂存摘战して $1^{\text {h }}$ 後に「cort. acet.」5mg/

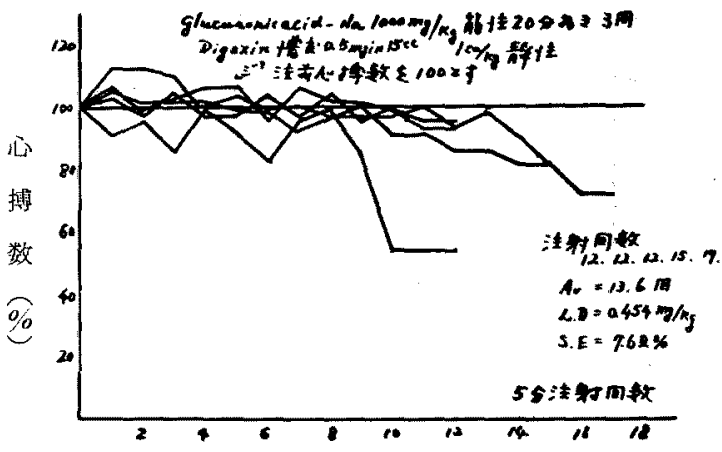

第13図b、Glucuronic acid-Na 前姏置モルモットの Digoxin L.D 㕲よび心撕曲線。

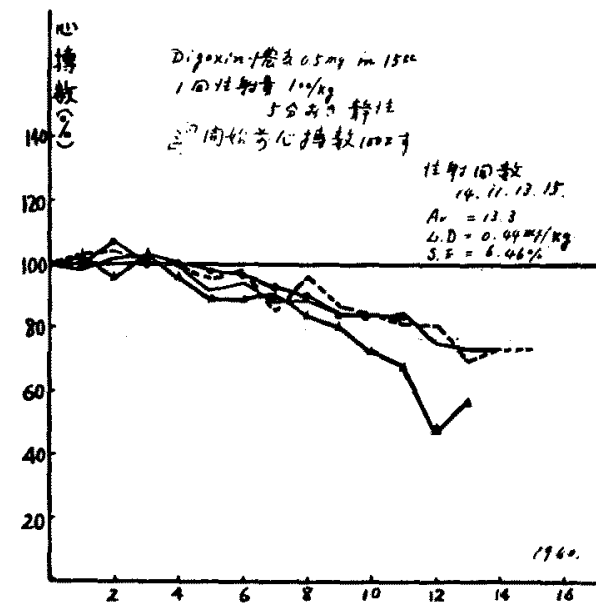

$5^{\mathrm{mn}}$ 和卷注射回数

第14图a.片側副腎摘出モルモットのDigoxin し。 D 和よび心搏曲線。 


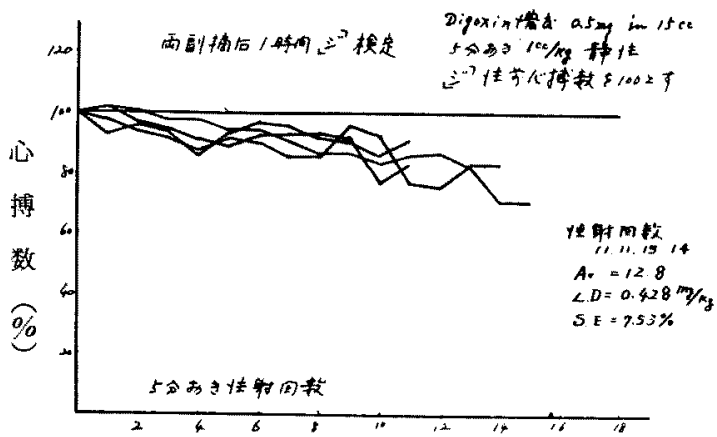

第14图b，雨副腎摘出モルモットの Digoxin L. D 打 よび心㧹曲線。

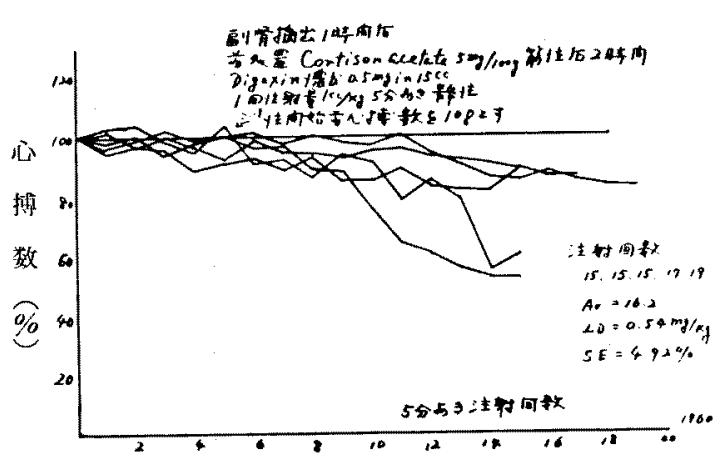

第15图，片㑡副简摘出モルモットのDigoxin L.D 和 よび心摲明線。

100g筋注し更に 2 b 後に Digoxin L.D 老测定せるに第15图に示すとおり 5 例平均 $0.54 \mathrm{mg} / \mathrm{kg}$ L.Dであって副 掔久如が「cort. acet.」投与によって機能回得を来たしているのが見られる。

4) 片側副腎摘出 $+\lceil$ gl. amid.」投与モルモットの「ジ」作用

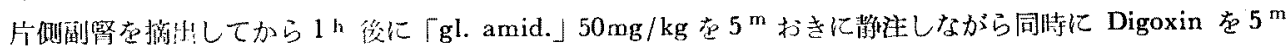

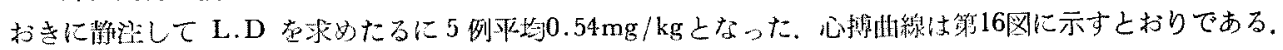

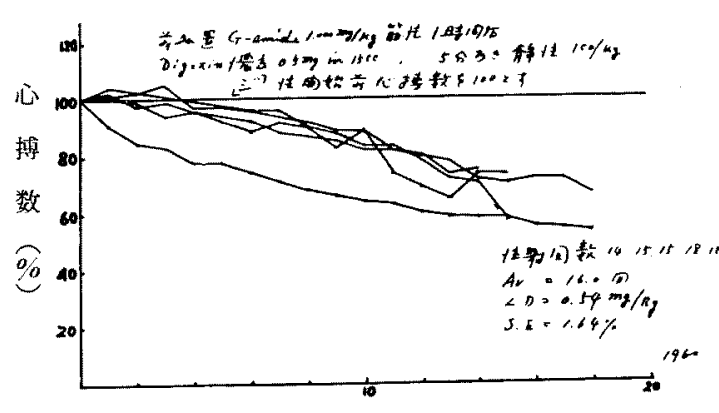

$5^{m}$ 㕲采拄射回数

第16図，片侧副腎掐出モルモットの Digoxin L.D 和

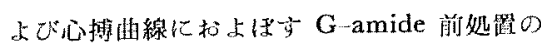
影触。

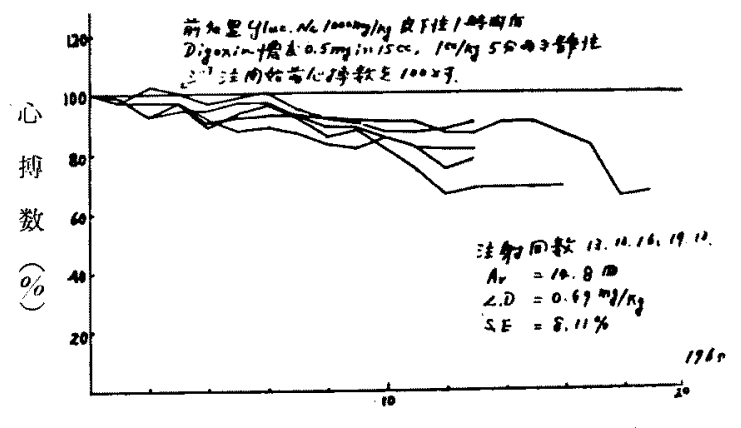

$5^{\mathrm{m}}$ 和意注射回数

第17图。片侧副腎摘出モルモットの Digoxin L.D

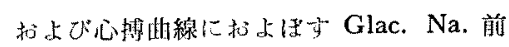

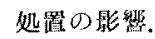

5）片側副蜸摘出 $+\lceil$ gl. not.」投与「モル」の「シ」作用

亟に前項「gl. amid.」の代りに同じような方法で「gl. nat.」を投与世る境合はDigoxin L.Dは第17图に見 るように 5 例取均 $0.49 \mathrm{mg} / \mathrm{kg}$ よなった。

6)小括

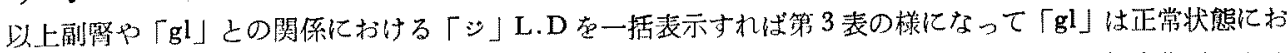
いては「モル」の「シ」作用に対して特別な相関は示さないが副紫機能不全の将は加なり明碓な解毒作用のある

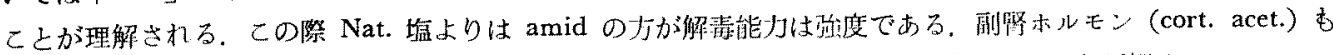

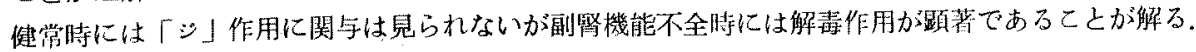

B） モルモットの素質転機と「ジ」作用

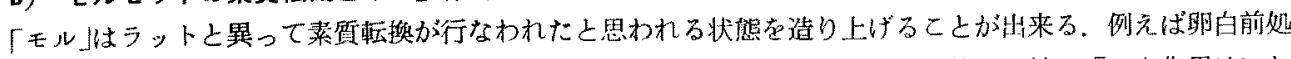
置 Diphthery toxin 前処置等は素質転換を来たした状熊と考えていい，乙う云う状熊に於て「シ」作用はいか 


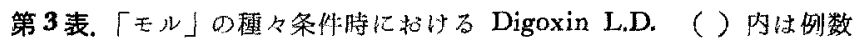

\begin{tabular}{|c|c|c|c|c|}
\hline モルモットの稪件 & $\begin{array}{c}\text { Digoxin L.D. } \\
\mathrm{mg} / \mathrm{kg}\end{array}$ & 注 射 回 & 平均回数 & 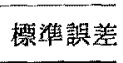 \\
\hline 正常モルモット & 0.525 & $13,14,15,18$ & 15 & $7.13 \%$ \\
\hline 正常「モル」gl. nat. & 0.454 & $12,12,12,15,17$ & 13.6 & $7.62 \%$ \\
\hline 正嘗「モル」 cort. acet. $(5$ & 0.545 & $14,15,15,19,20$, & 16.4 & $7.38 \%$ \\
\hline Vagus 切 断 & 0.287 & $5, \quad 7, \quad 9,10,10$, & 8.6 & $14.0 \%$ \\
\hline 出側副蜸摘出 & 0.44 & $11,13,14,15$ & 13.3 & $6.46 \%$ \\
\hline 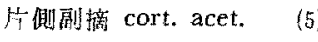 & 0.54 & $15,15,15,19,19$ & 16.2 & $4.92 \%$ \\
\hline 扩㑡副蔐+gl. amid. & 0.54 & $14,15,15,18,18$ & 16.0 & $1.64 \%$ \\
\hline 纺㑡副摘 + gl. nat. & 0.49 & $13,13,13,16,19$ & 14.8 & $8.11 \%$ \\
\hline 闭側解摘 & 0.428 & $11,11,14,15$ & 12.8 & $7.53 \%$ \\
\hline
\end{tabular}

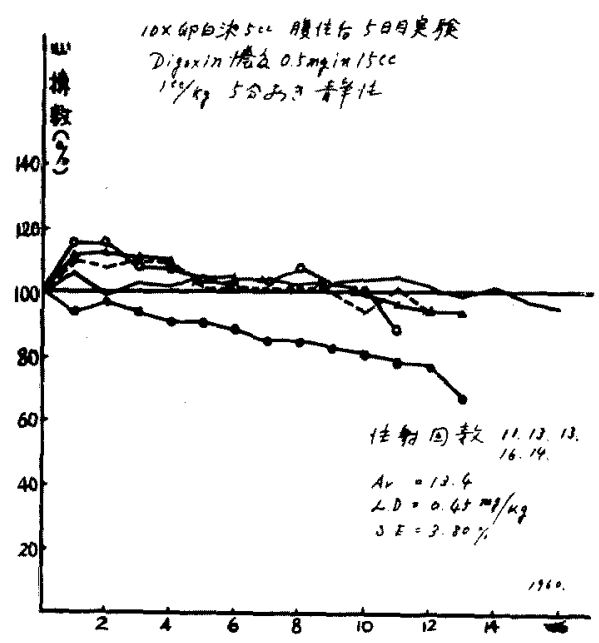

$5^{\mathrm{m}}$ 和豆这射回数

第18図. 即白前起埴モルモットの Digoxin L.D 㭁 よび心搏作用。

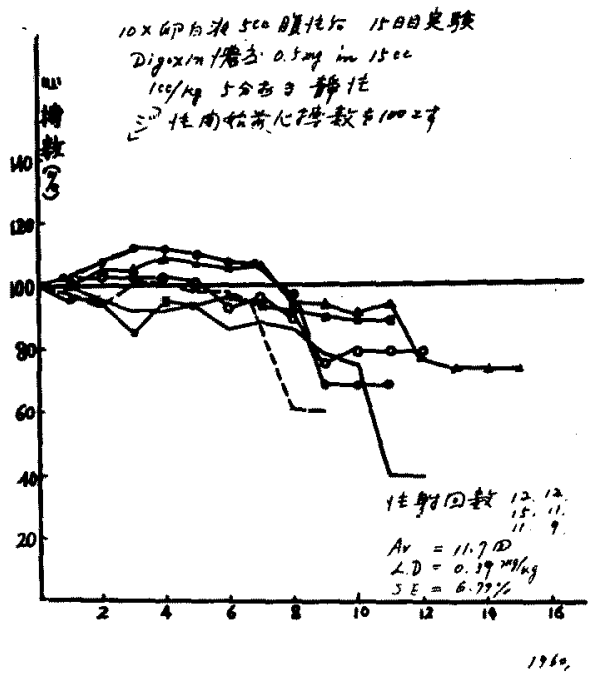

$5^{\mathrm{m}}$ 施注射回数

第19図、卵白前処置モルモットの Digoxin L.D 执よび心捕作用。
に変るだろうか。

1）熶白前姑置「モル」の「ジ作用

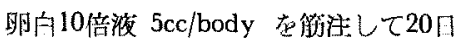
経過寸ればこのモルモットは卵古に刘し

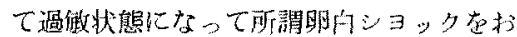
こす。この明门「モル」は外兒十は正常厄 ル」と何等変りは見られないが penicillin

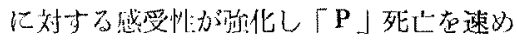
万。

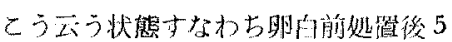
日目の「モル」の Digoxin L.D 在測定世

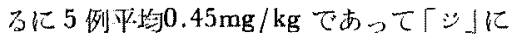

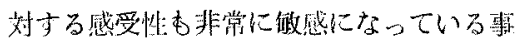

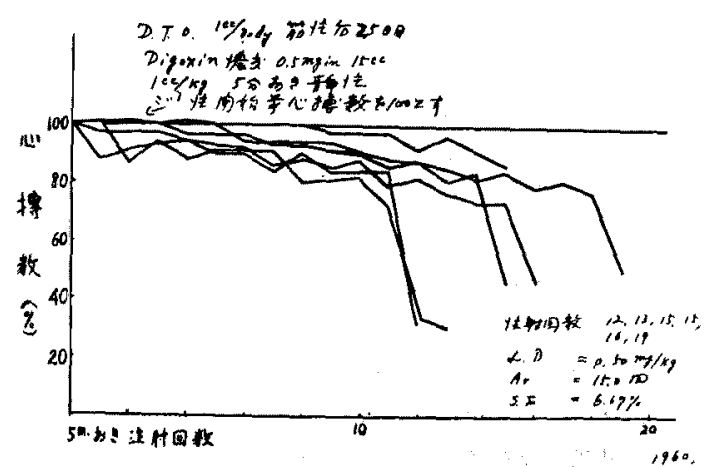

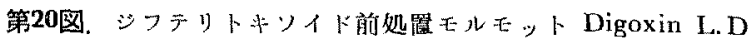
把よび心搏作朋。 


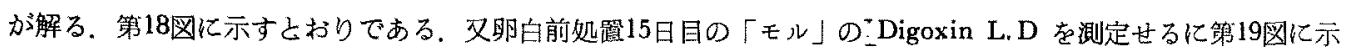
すように 6 例平均 L.D $0.39 \mathrm{mg} / \mathrm{kg}$ であって「シ」感受性が更に强化しているととが解る.

2) DTO 前処置「モル」の「ジ」作用

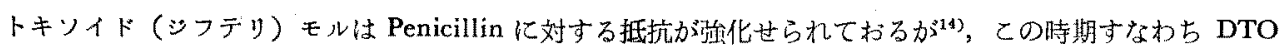

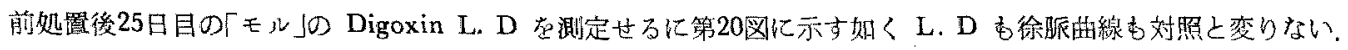
Digoxin L.D は 6 例平均 $0.50 \mathrm{mg} / \mathrm{kg}$ であった。

C)「モル」の「ジ」心搏作用

「cort. acet.」を前処置せる「モル」の方が正常「モル」よりも「シ」心搏緩徐の程度は柽度である(第 3 ，

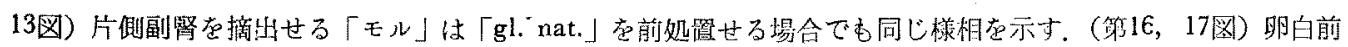

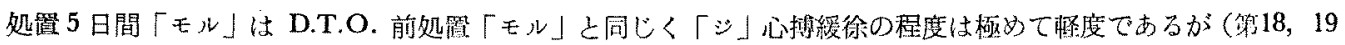

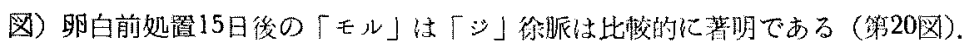

\section{総括並びに考察}

以上実験データな一括表示す礼ば

\begin{tabular}{|c|c|c|c|c|}
\hline & ラット L. D. & & & モルモット L. D. \\
\hline $\begin{array}{l}\text { 正 裳 動 哆 } \\
\text { gl. nat. } \\
\text { cort. acet. } \\
\text { 副'蜸 摘 出 } \\
\text { 副摘+gl. nat. } \\
\text { 副摘+gl. amid. } \\
\text { 㣂摘+cort. acet. } \\
\text { Vagus 切 断 }\end{array}$ & 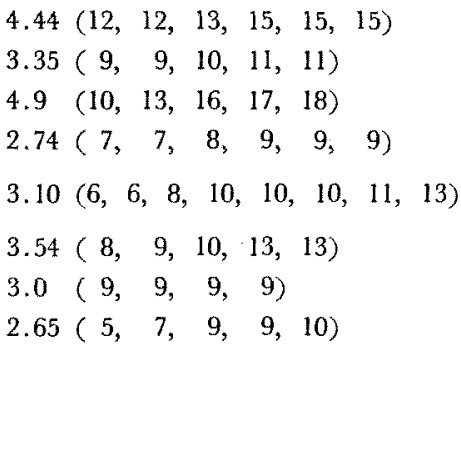 & 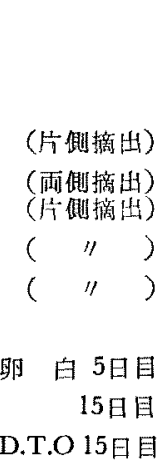 & $\begin{array}{l}0.525 \\
0.454 \\
0.545 \\
0.44 \\
0.428 \\
0.49 \\
0.54 \\
0.54 \\
0.287 \\
0.45 \\
0.39 \\
0.50\end{array}$ & $\begin{array}{l}(13,14,15,18) \\
(12,12,12,15,17) \\
(14,15,15,19,20) \\
(11,13,14,15) \\
(11,11,14,15) \\
(13,13,13,16,19) \\
(14,15,15,18,18) \\
(15,15,15,17,19) \\
\left(\begin{array}{rr}5, & 7, \\
(11,13,13,13 & 14,16) \\
(9,11,11,12,12,15) \\
(12,13,15,15,16,19)\end{array}\right.\end{array}$ \\
\hline
\end{tabular}

(1) 猫，「モル」及び䲩は Digoxin L.D は大体 $0.5 \mathrm{mg} / \mathrm{kg}$ 前後であるがラットは 8 倍以上 $4.45 \mathrm{mg} / \mathrm{kg}$ で ある。

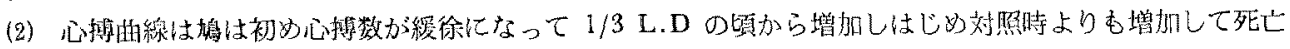

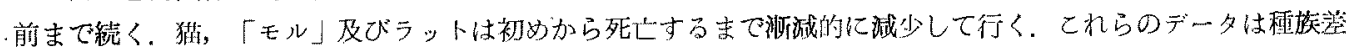

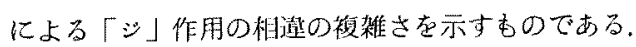

(3) ラットの「シ」作用

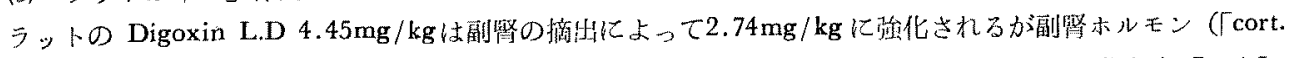

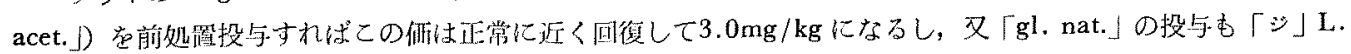
$\mathrm{D}$ 緮和せしめて3.05 $\mathrm{mg} / \mathrm{kg}$ になる。

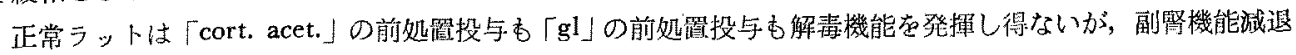

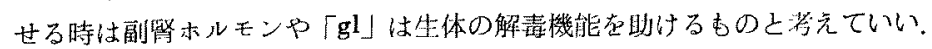

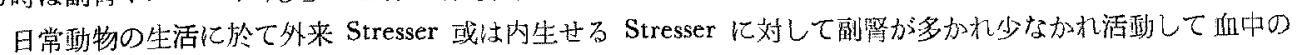

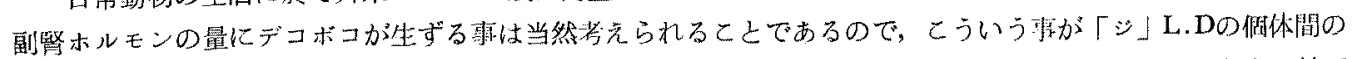

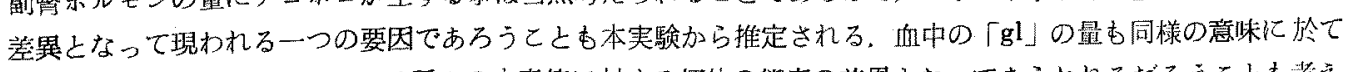

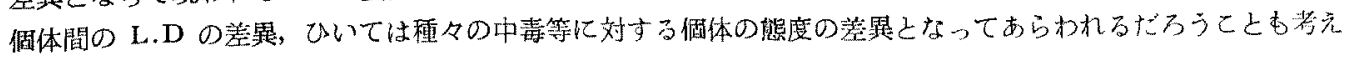
られる。 
(4)「モル」の「シ」作用

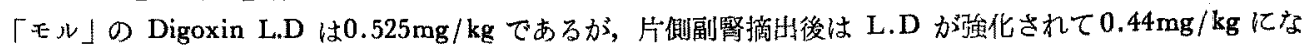

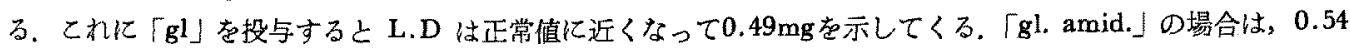
$\mathrm{mg} / \mathrm{kg}$ 亿なって正常上変りなくなる。次に両側副腎摘出の場合住 Digoxin L.D は $0.428 \mathrm{mg} / \mathrm{kg}$ となって，片側 副摘の場合上左程大きな相違は見られない。

これに反し正常「モル」では「シ」L.D亿対して副睯ホルモンや「gl」の影響ば見られない．

以上の事実加ら「モル」に於てもラットに於けると同じように，正常時に於ては副瞥水ルモンや「 L.Dに対する影響は見られないが「モル」の副腎機能低下時はその L.D に対して解毒的作用を営んでいる禾の

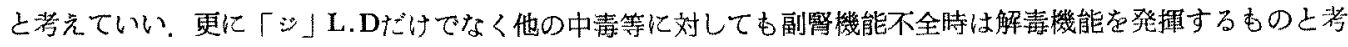
えていい.

副腎摘出によって「シ」L.Dが著明に強化する報告 ${ }^{12}$ 住多数に存在するが吾々の実験ではラットです「モル」 でむ $1 / 2$ 以上に强化はしないが，副摘の影響は「モル」よりもラットの方が顕著である.

(5) アレルギー菜筫と「シ」作用

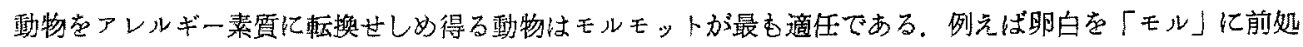
䁂する時は15日経過す机ばその「モル」は卵白に対して非常に過敏になって卵白の再度静注によって Anaphylaxy Shock を扎して死亡する. シフテりアトキソイト（D.T.O）であ全く同様である．しかしその他の生活状態や 生活热度は正常「モル」と何等変りが㓋いが最近は

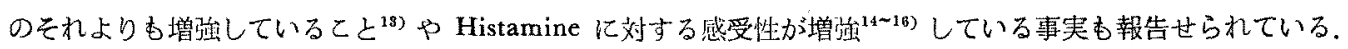

しかしその增強の程度は畉白やDTO 亿対する感受性增強の程度に比ぶれば非常に僅少である，処が教室に

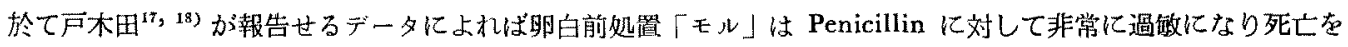
促進するが，DTO 前処置「モル」は Penicillin に対する抵抗力が增強されて，Penicillin 死亡を来たさないで 救助出来るようになった．即ちアレルギー素望であ抗原の種類によって「P」に対する生体反応が相遠してきて

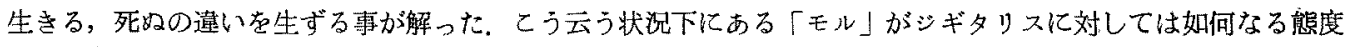

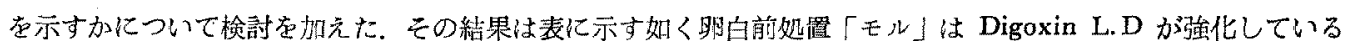
がその反対に DTO「モル」は Penicilin fest になっただけでなく Digoxin L.D は対照正常「モル」と全く同 じであった．此のデータは卵白やDTOに限らず何等かの似たような Stresser が生体に加觉られれば Stresserの 種類によっては「モル」の「シ」L.Dが少しずつ変動するととがある事草示唆するあのである，かくして個体間 の「シ」感受性の差異が形成世られるものと考元ていい.

又血中「 $\mathrm{gl} 」$ 解毒関与しているもの之考えていいし，ひいては動物の素質の要因の一つを形成している こと李想像される.

\section{結 論}

以上「シ」の感受性に対する動物の菜質上の条件ししては種族差は最む著明である。阿して，感受性の偑体

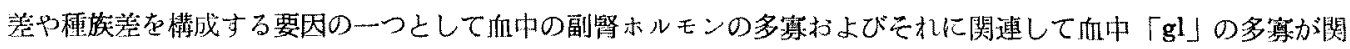

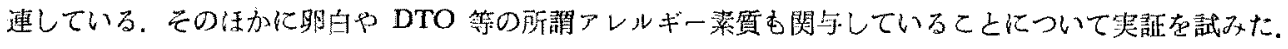

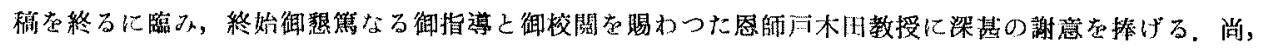
グロンサン及び Scheroson の提供をうけた中外製薬之日独䌝品飞感謝す。

\section{文献}

1) 万木田たち：棕合医学 12，10，673〜689 (1955).

2) 小田原鶴吉：日染理誌 56, 1522 1528 (1959).

3) 万林田たち：綜合医学 14, 9, 815 823 (1957),

4) 第 6 回日本薬局洼 : 
5) 今木由，荒洔：日薬理誌 48，809（1952）。

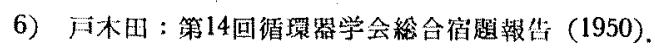

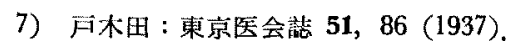

8) 岡田擽：日摹理誌 57, 1 (1961).

9) 椎原德廐：同誃 57, 1 (1961).

10）角尾：第 6 回グルタロンサン研究発裁 $(1961 ， 7 ， 24)$.

11）歶谷利明：第 6 回ダルクロンサン研究発表会 $(1961 ， 7 ， 24)$.

12) Lewis, Kuhlman, Delblue, Keept, : Thorn. Endo crinol. 27, 971 (1940).

13) 渡辽：フレルギー9，6，537〜543 (1960).

14) Dale, H. H. : Brit. J. Exp. path. 1, 103 (1920).

15) Cri vellari, C. A. : am. J. Physiol. 130, (1940).

16) Ingle, D. J. am. J. Physiol. : 118, 57 (1937).

17) F柚たち：日薄理誌 56, 421〜426 (1960).

18) 戸米田たち：同誌 56, 427-437 (1960). 